\title{
U-Pb Age and Hf Isotopic Compositions of Magmatic Zircons from a Rhyolite Flow in the Porcellanite Formation in the Vindhyan Supergroup, Son Valley (India): Implications for Its Tectonic Significance
}

\author{
Marion E. Bickford, ${ }^{1}$ Meenal Mishra, ${ }^{2}$ Paul A. Mueller, ${ }^{3}$ George D. Kamenov, ${ }^{3}$ \\ Juergen Schieber, ${ }^{4}$ and Abhijit Basu, ${ }^{4}$ * \\ 1. Department of Earth Sciences, Syracuse University, Syracuse, New York 13244-1070, USA; 2. School of Sciences, \\ Indira Gandhi National Open University, New Delhi 110068, India; 3. Department of Geological Sciences, \\ University of Florida, Gainesville, Florida 32611, USA; 4. Department of Geological Sciences, \\ Indiana University, Bloomington, Indiana 47405, USA
}

\begin{abstract}
A B S T R A C T
The Porcellanite Formation in the basal Semri Group of the Proterozoic Vindhyan Supergroup, exposed along the Son River Valley, India, primarily consists of intercalated silicified felsic tuff beds (porcellanite), rhyolitic breccia, and shale. Lensoid patches of very coarse-grained rhyolite occur in a stretch of about $10 \mathrm{~km}$ near the eastern end of the valley. These are newly interpreted as rhyolite flows, with flow structures including aligned volcanic fragments and phenocrysts, a few of which are $\sim 10$-cm-long feldspars. Microphenocrysts consist of fragments of patchy perthite and quartz, with subordinate Fe-oxide minerals set in a very fine-grained groundmass of quartz and feldspar. Volcanic rock fragments and fiamme are common. Bulk chemical compositions of nine samples also identify them as rhyolite $\left(\mathrm{SiO}_{2}=75.24 \% ; \mathrm{Na}_{2} \mathrm{O}+\mathrm{K}_{2} \mathrm{O}=7.06 \%, \mathrm{CaO}=1.66 \%\right)$. Rare earth element distribution is typical of granitic rocks, with a negative Eu anomaly of 0.57 . The samples are enriched in $\mathrm{U}, \mathrm{Th}, \mathrm{La}$, and $\mathrm{Rb}$ and depleted in $\mathrm{Cr}$ and $\mathrm{Ni}$ relative to upper continental crust and total crust. New U-Pb isotopic analyses of magmatic zircons in the rhyolitic flow give a concordia intercept age of $1640 \pm 4 \mathrm{Ma}$ and a weighted-mean ${ }^{207} \mathrm{~Pb} /{ }^{206} \mathrm{~Pb}$ average age of $1642 \pm 7 \mathrm{Ma}$. These are essentially identical with those determined previously from zircons in porcellanite outcrops to the west. Lu-Hf isotopic compositions show that all but one $\varepsilon_{\mathrm{Hf}}$ value at $1640 \mathrm{Ma}$ are less than chondrite uniform reservoir values, indicating a significant contribution from older, felsic crust. Crustal models suggest derivation from about $2.5 \mathrm{Ga}$ middle to lower crust. The new data do not support Semri sedimentation in an active arc setting or derivation of the rhyolite magma from a putative and now-concealed subduction zone with contribution from the mantle. We suggest that far-field effects of one or more of the ca. $1650 \mathrm{Ma}$ collisions of continental blocks caused crustal fracturing as the basin subsided, which induced melting and the consequent rhyolitic volcanism.
\end{abstract}

Online enhancements: appendix tables.

\section{Introduction}

The Purana Basins of peninsular India (Ramakrishnan and Vaidyanadhan 2010), in general, preserve essentially flat-lying and largely undeformed, kilometers-thick Proterozoic sedimentary rocks, except at their margins. The largest is the Vindhyan basin in northern India; its extent is $>200,000 \mathrm{~km}^{2}$,

Manuscript received August 15, 2016; accepted January 10, 2017; electronically published March 14, 2017.

* Author for correspondence; e-mail: basu@indiana.edu. including extensions into the subsurface, and it is estimated to include $3-5 \mathrm{~km}$ of sedimentary rocks. The strata are well exposed and largely accessible and have been studied for decades (Mallet 1869; Auden 1933; Mathur 1982; Bhattacharyya 1996; Bansal and Dimri 2001; Chakraborty 2006; Kumar and Sharma 2010; Bose et al. 2015). Despite the vastness of the Vindhyan sedimentary rocks (Vindhyan Supergroup), there is little consensus about details, in particular absolute ages, facies relationships, intrabasinal unconformities, tectonic setting, and the extent and causes of 
intrabasinal volcanism. For example, various authors have proposed arc, foreland, rift, or pericratonic environments for Vindhyan sedimentation.

Volcanism, as recorded by silicified ash, or "porcellanite," beds, has been previously reported within the Chopan member of the Semri Group (Lower Vindhyan; Rasmussen et al. 2002; Ray et al. 2002) and in the Rampur Shale of the upper Semri Group (Rasmussen et al. 2002). In this article, we report on the chemical compositions and ages of zircons from an unusually coarse-grained, somewhat brecciated, pyroclastic, and true rhyolite flow associated with ash beds near Kon in the eastern end of the Vindhyan basin (fig. 1). The focus of this article is the U-Pb age of zircons, their Hf isotopic compositions, and interpretation of these new data toward understanding the geological and tectonic significance of early (ca. 1642-1628 Ma) silicic volcanism in the Vindhyan basin.

\section{Geological Setting}

Stratigraphy. The Vindhyan Supergroup includes essentially undeformed (except at basin margins) and unmetamorphosed sedimentary rocks that crop out mostly in north-central India and unconformably overlie the Paleoproterozoic Mahakoshal Group. The supergroup includes four groups (table 1). The Semri
Group, at the base, is unconformably overlain by the three other groups: Kaimur, Rewa, and Bhander in ascending order.

Occurrence and Age of Volcanic Rocks in the Semri Group. The occurrence of volcanic rocks in the Semri Group has been known for decades. Mallet (1869, p. 28-38) described two layers of silicified beds as "Porcellanic shales," which occur above and below "Trappoid beds" in the Semri Group in the Son River valley in north-central India (fig. 1; table 1). Auden (1933) identified these as felsic ash beds and termed them "porcellanites." These beds, on average about $1 \mathrm{~m}$ thick, alternate between laminated tuff of different shades of gray, off-white, black, and green and pyroclastic rocks comprising clasts of varying size, volcanic breccia, volcanic bombs, and shale. The unit is mapped as the Porcellanite Formation; it is also known as the Deonar or Chopan Porcellanite Formation. The formation, but not all beds, can be tracked laterally for over $300 \mathrm{~km}$ in an approximately NNE-SSW linear swath (fig. 1). Srivastava et al. (2003, p. 178) recognized "three distinct volcanic eruptions" represented by ash beds east of Chopan, but Ghosh (1971) identified only two, near Semariya WSW of Sidhi and south of Chorhat (fig. 1). U-Pb TIMS ages of magmatic zircons from an ash bed near Kuteswar (fig. 1) average $1631 \pm 5 \mathrm{Ma}$ (Ray et al. 2002). SHRIMP ages of magmatic zircons from the top of the Por-

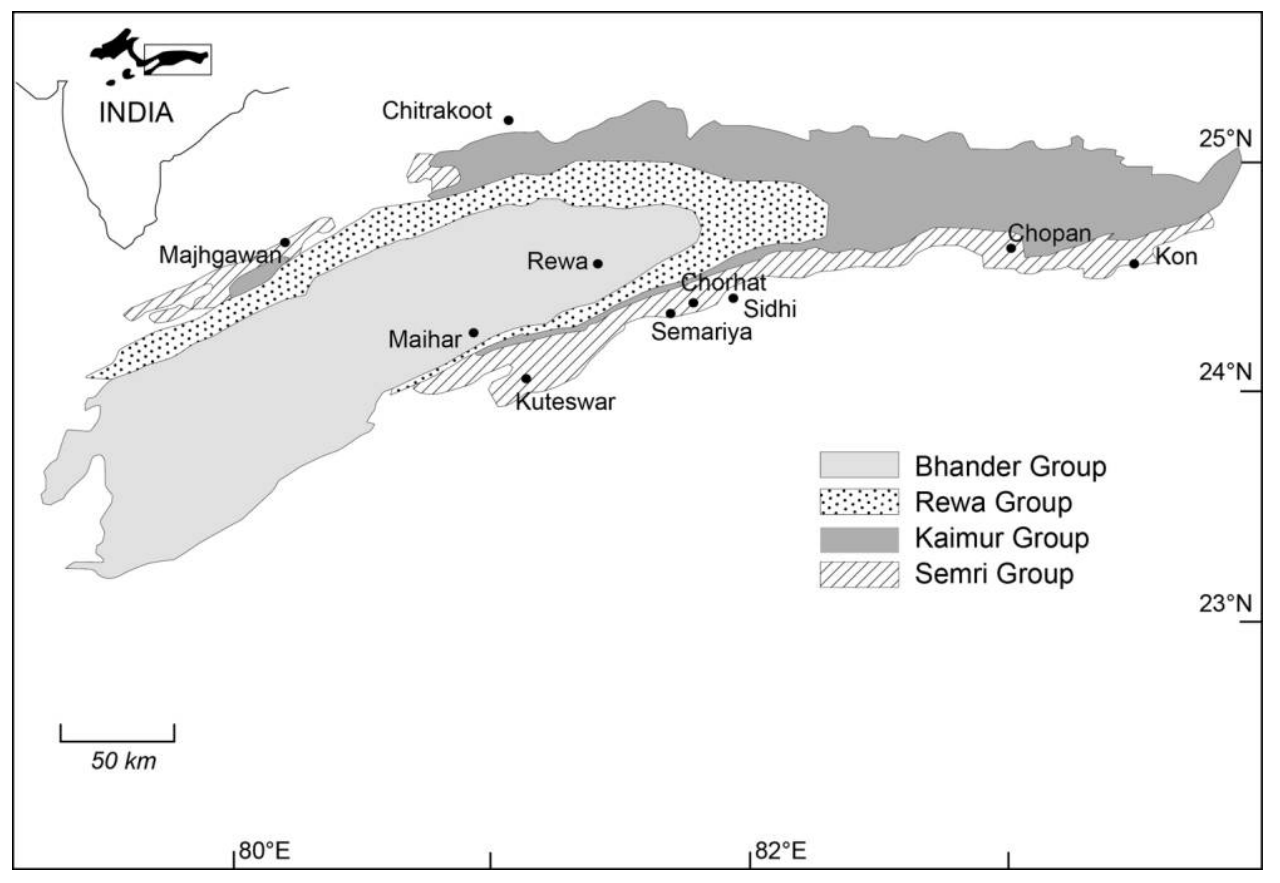

Figure 1. Geological map of the eastern part of the Vindhyan basin. Samples used in this study are from near Kon. Adapted from Ray et al. (2002). 
Table 1. Simplified Stratigraphy of the Vindhyan Supergroup in the Son Valley

\begin{tabular}{|c|c|c|c|}
\hline Group, formation & Member & Age (Ma) & References for age \\
\hline \multicolumn{4}{|l|}{ Bhander } \\
\hline \multicolumn{4}{|l|}{ Rewa } \\
\hline \multicolumn{4}{|l|}{ Kaimur } \\
\hline \multicolumn{4}{|l|}{ (Unconformity) } \\
\hline \multicolumn{4}{|l|}{ Semri: } \\
\hline \multicolumn{4}{|l|}{ Suket Shale } \\
\hline \multirow[t]{3}{*}{ Rohtas Limestone } & & $1599 \pm 48$ & Sarangi et al. 2004 \\
\hline & & $1601 \pm 130$ & Ray et al. 2002, 2003 \\
\hline & Rampur Shale & $1593 \pm 12,1602 \pm 10$ & Rasmussen et al. 2002 \\
\hline Chorhat Sandstone & Tirohan Limestone & $1650 \pm 89$ & Bengston et al. 2009 \\
\hline \multicolumn{4}{|l|}{ Bargawan Limestone } \\
\hline \multicolumn{4}{|l|}{ Khenjua/Koldaha Shale } \\
\hline \multirow[t]{5}{*}{ (Chopan) Porcellanite } & Greenish/opaline tuff & $1628 \pm 10$ & Rasmussen et al. 2002; \\
\hline & & $1631 \pm 5$ & Ray et al. 2002 \\
\hline & Massive tuff & & \\
\hline & Banded tuff & & \\
\hline & Rhyolite & $1642 \pm 7$ & This work \\
\hline Kajrahat Limestone & & $1729 \pm 110$ & Sarangi et al. 2004 \\
\hline \multicolumn{4}{|l|}{ Arangi Shale } \\
\hline \multicolumn{4}{|l|}{ Deoland Sandstone } \\
\hline \multicolumn{4}{|l|}{ (Unconformity) } \\
\hline \multicolumn{4}{|l|}{ Mahakoshal: } \\
\hline Jhirgadandi Granite & & $1753 \pm 9$ & Bora et al. 2013 \\
\hline
\end{tabular}

Note. Groups, formations, and members are listed from uppermost to lowermost.

cellanite Formation and another ash bed, some $350 \mathrm{~m}$ above, in the Rampur Shale near Chorhat (fig. 1) yielded $1628 \pm 8$ and $1599 \pm 8 \mathrm{Ma}$, respectively (Rasmussen et al. 2002). Bose et al. (2001) considered the latter ash bed to have been resedimented and presumably not a primary igneous deposit. However, in view of multiple occurrences of ash flow deposits in the Vindhyan Supergroup (e.g., P. Chakraborty et al. 1996; Sen and Mishra 2014), we consider the Rampur bed at $1599 \mathrm{Ma}$ to be of igneous origin. In the context of geological age (table 1), it is important to note that the Lower Vindhyan Semri Group has been considered to be Ediacaran (619-542 Ma) by many paleontologists (e.g., Prasad and Asher 2016 and references therein), contradicting radioisotopic geochronology.

Occurrence of Coarse Rhyolite. Silicified ash beds constitute most of the volcanic material in the Porcellanite Formation. A small body of rhyolite displaying distinctive flow structures (fig. 2), containing large lithic and crystal fragments, and intercalated with silicified ash beds crops out near the villages of Doma and Dewatan in the Chanchikhurd area, immediately NNW of Kon $\left(24^{\circ} 25^{\prime} 6.5^{\prime \prime} \mathrm{N}, 83^{\circ} 22^{\prime} 7.38^{\prime \prime} \mathrm{E}\right.$ fig. 1). Although, as indicated above, the porcellanite beds have been extensively studied (Mishra and Sen 2010 and references therein), the rhyolite flow, which may be parental to the porcellanite ash beds, has not previously been dated or studied petrologically.
The soft rocks of the Porcellanite Formation are exposed all along the northern and southern banks of the Son River. The outcrops of the rhyolite, which are lensoid and whose total exposure is $\sim 50 \mathrm{~m} \times 10 \mathrm{~km}$, are exposed on the southern bank of the Son River in the Chanchikhurd area in the eastern part of the Son valley. The rhyolite body, or flow, is underlain by flat-lying, buff-colored, fine-grained tuff and overlain by a banded variety of porcellanite. As noted, the rhyolite includes large angular lithic clasts and crystal fragments aligned in the flow direction (fig. 2). Feldspar phenocrysts measuring $\sim 10 \mathrm{~cm}$ in length have been observed.

For this study, we collected samples near the Doma village $\left(24^{\circ} 27^{\prime} 40.8^{\prime \prime} \mathrm{N}, 83^{\circ} 22^{\prime} 8.74^{\prime \prime} \mathrm{E}\right.$; DOMA-1, $2,2 \mathrm{~A}, 4,5,6,7)$ and the Dewatan village $\left(24^{\circ} 27^{\prime}\right.$ $28.2^{\prime \prime} \mathrm{N}, 83^{\circ} 20^{\prime} 12.1^{\prime \prime} \mathrm{E}$; DEW-8, 10). Singh and Srivastava (1982) and Srivastava et al. $(2001,2003)$ have described pyroclastic breccia, pumice tuff, and agglomerate tuff from the Chanchikhurd-Kon area; Ghosh (1971) also described lithic agglomerate tuff, lapilli tuff, banded chert to fine tuffaceous sediments, and large bombs near Semariya; Bhattacharjee et al. (1964) have tracked pyroclastic rocks from Chopan to Sidhi; Mehrotra et al. (1985) described "conglomeratic" porcellanite in outcrops in between Chopan and Sidhi; and T. Chakraborty et al. (1996) have described the sedimentological, stratigraphic, and petrologic aspects of these rocks from outcrops that occur to the southwest of Semariya. Remnants of three suspected 


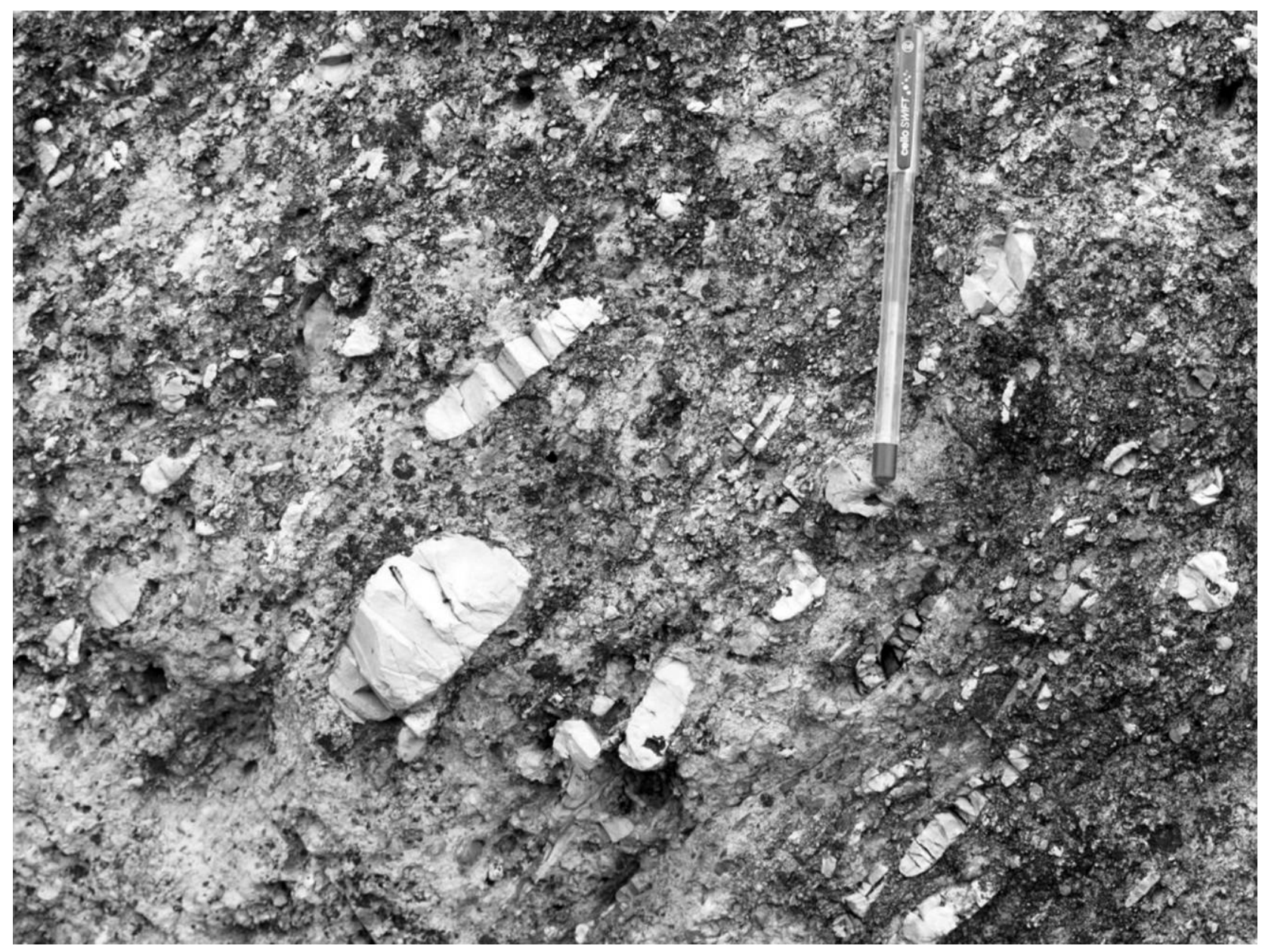

Figure 2. Close-up photograph of the rhyolite outcrop. Volcanic fragments and broken and unbroken phenocrysts, including large feldspars, are aligned in the flow direction. The pen is about $15 \mathrm{~cm}$ in length.

volcanic vents are exposed at Kon $\left(24^{\circ} 25^{\prime} 6.5^{\prime \prime} \mathrm{N}, 83^{\circ}\right.$ $\left.22^{\prime} 07.38^{\prime \prime} \mathrm{E}\right)$ and Khempur $\left(24^{\circ} 26^{\prime} 27.7^{\prime \prime} \mathrm{N}, 83^{\circ} 19^{\prime} 20.4^{\prime \prime} \mathrm{E}\right)$ and may be related to explosive volcanic activity.

\section{Petrography}

Polished thin sections were examined in both transmitted and reflected light as well as by a scanning electron microscope in back-scattered electron mode (SEM-BSE) and via energy-dispersive spectroscopy (SEM-EDS). The rhyolite samples (DOM and DEW) show brecciated texture, with angular lithic and mineral clasts of various sizes (a few exceed $5 \mathrm{~mm}$ in length) and composition. The lithics are principally tuffaceous materials, including dark pumice fragments and fiamme (sensu Bull and McPhie 2007). In reflected light, the latter appear to be a mixture of very fine-grained Fe-Ti oxide minerals (altered to limonite/leucoxene), feldspar, and very minor quartz; glass and vacuoles have not been observed.
The mineral clasts are mostly fragments of phenocrysts of patchy perthite and quartz. Feldspar fragments are much larger than quartz fragments (fig. 3a). Patchy perthite, extensively altered to clay (fig. $3 b$ ) but easily and abundantly observed in SEM-BSE images, is the most abundant large phenocryst (fig. 3c, 3d). Although the clay minerals are not identifiable in thin sections, they are compositionally (as seen via BSE intensity and EDS) sufficiently different to define their parental K-spar or plagioclase domains. Plagioclase domains commonly exhibit ghost twin lamellae. Individual grains of plagioclase and K-spar appear to be broken fragments and are possibly pieces of the much larger patchy perthites. Phenocrysts of quartz are clear and commonly curved or angular, with curvilinear fracture lines and rare isolated vacuoles. They do not commonly show the bipyramidal or prismatic shapes typical of phenocrysts in associated felsic ash, and embayment is also very rare. The matrix is a very fine-grained mosaic of quartz and 

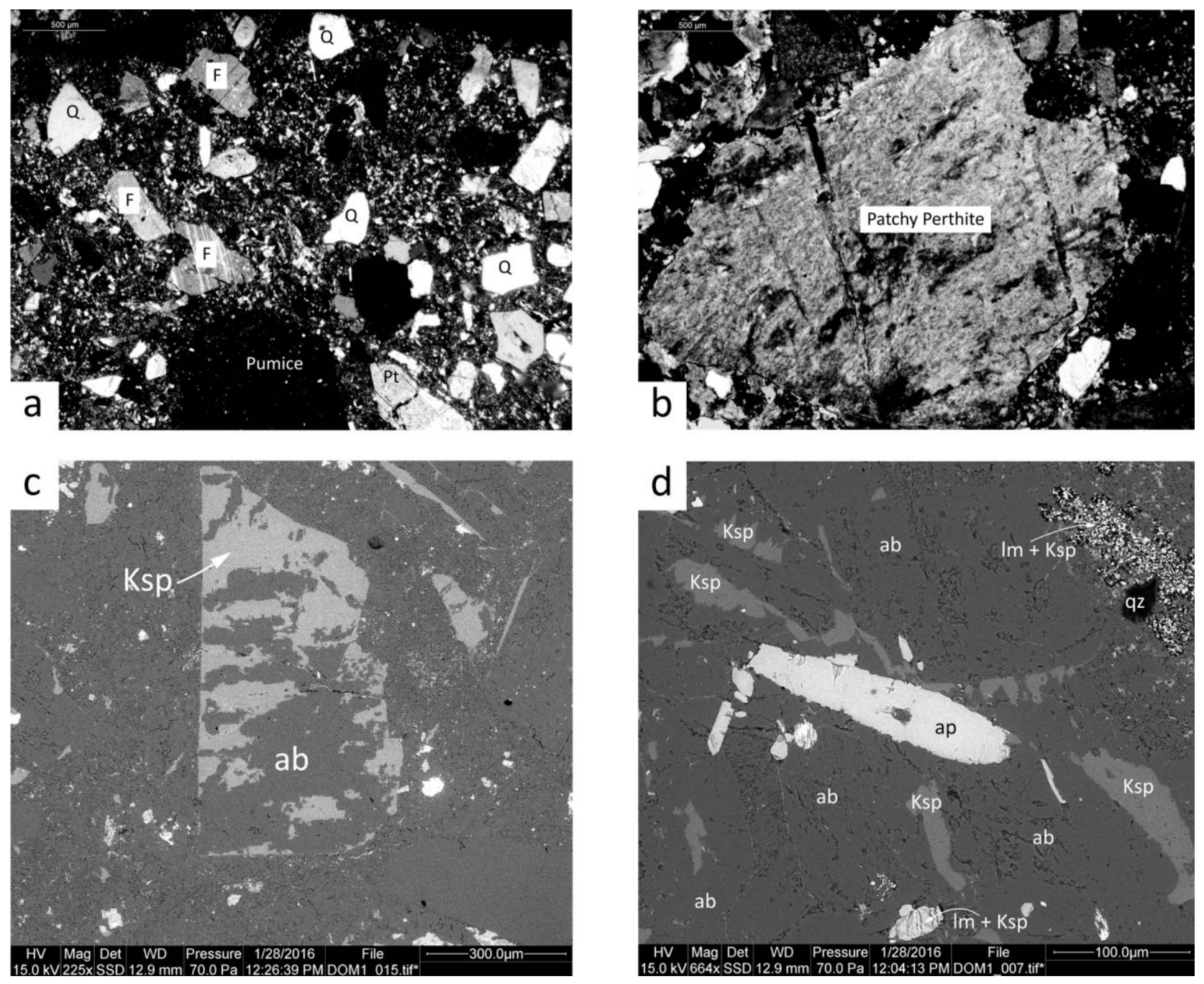

Figure 3. $a$, Photomicrograph under crossed polarizers, showing the mineral composition and the general texture of the rhyolite. Note the fragmentary nature of the grains in different sizes. Feldspar phenocrysts (perthite $[\mathrm{Pt}])$ are larger than others. $\mathrm{F}=$ plagioclase; $\mathrm{Q}=$ quartz. Scale bar $=500 \mu \mathrm{m}$. $b$, Large patchy perthite almost completely altered to a variety of clay minerals. The K- and Na-rich ghost domains show different shades of gray. Scale bar $=500 \mu \mathrm{m}$. $c$, SEMBSE (scanning electron microscope in back-scattered electron mode) image of patchy perthite; K-spar (Ksp) is dominant over albite $(\mathrm{ab})$; ilmenite is very bright. Scale bar $=300 \mu \mathrm{m} . d$, SEM-BSE image of patchy perthite; albite (ab) is dominant over K-spar (Ksp); fragments of apatite (ap) are larger than the domains of limonite $(\operatorname{lm})+\mathrm{Ksp}$. qz $=\mathrm{quartz}$. Scale bar $=100 \mu \mathrm{m}$.

feldspar but does not have obvious shards; it appears to have been fine ash. Apatite and ilmenite are the principal accessory minerals (fig. 3 d). Secondary minerals include leucoxene, limonite, and carbonates.

\section{Geochemistry}

Chemical compositions of nine whole-rock samples of the rhyolite were obtained at Activation Lab in Ancaster, Canada, and are given in table A1 (tables A1-A3 available online). The average LOI (loss on ignition)-free $\mathrm{SiO}_{2}$ content of the rhyolite samples is $75.24 \%( \pm 1.80 \%), \mathrm{Na}_{2} \mathrm{O}+\mathrm{K}_{2} \mathrm{O}$ is $7.06 \%$ $( \pm 0.64 \%)$, and $\mathrm{CaO}$ is only $1.66 \%( \pm 0.58 \%)$, thus chemically classifying the rocks as rhyolite (average $\mathrm{LOI}=2.44 \% \pm 1.01 \%$ ). A plot of $\mathrm{SiO}_{2}$ versus $\mathrm{Zr} / \mathrm{TiO}_{2}$ (fig. 4A; Winchester and Floyd 1977) also classifies the rocks as rhyolite, but a plot of $\mathrm{Zr} / \mathrm{Ti}$ versus $\mathrm{Nb} / \mathrm{Y}$ (fig. 4B; Pearce 1996) puts them in the subalkalic rhyodacite field. Chondrite-normalized plots of the rare earth element (REE) abundances in these samples (fig. 5; Sun and McDonough 1989) show enrichment in light REEs, nearly flat depleted heavy REEs, and a moderate negative Eu anomaly 

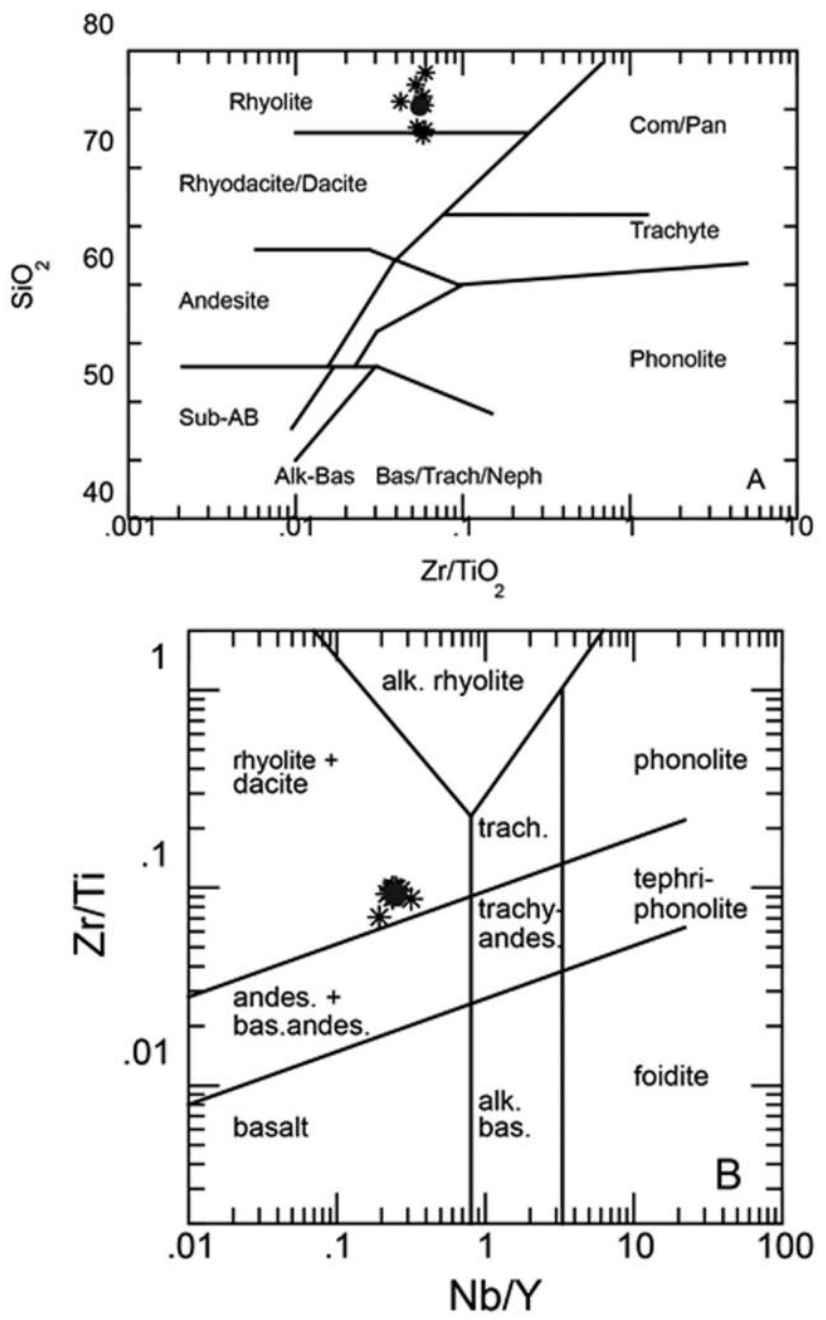

Figure 4. Chemical compositions classify the samples as rhyolite. The nine stars represent individual DOM and DEW samples, and the filled circle represents their average. Top, $\mathrm{SiO}_{2}$ versus $\mathrm{Zr} / \mathrm{TiO}_{2}$ plot after Winchester and Floyd (1977); AB, Alk-Bas = alkaline-basalt; Bas/Trach/Neph = basanite/trachybasanite/nephelinite; Com/Pan = comendite/ pantellerite; B, Zr/Ti versus Nb/Y plot after Pearce (1996); alk. $=$ alkaline; andes. $=$ andesite; bas. $=$ basalt ; trach. $=$ trachyte; trachyandes. $=$ trachyandesite.

$(0.57 \pm 0.03)$ typical of granitic rocks. Relative to the estimated composition of the upper continental crust (UCC: Rudnick and Gao 2003), Rb is enriched and $\mathrm{Sr}$ is steeply depleted, compatible with the relatively high $\mathrm{Na}_{2} \mathrm{O}+\mathrm{K}_{2} \mathrm{O}$ and low $\mathrm{CaO}$ contents of the samples (fig. 6; Taylor and McLennan 1985; Rudnick and Fountain 1995). Further, U, Th, La, Ce, $\mathrm{Nd}, \mathrm{Sm}$, and $\mathrm{Y}$ are enriched, $\mathrm{Ta}$ and $\mathrm{Zr}$ are slightly enriched, and $\mathrm{Nb}$ is moderately depleted. These relationships do not change if the comparison is made with the estimated composition of the total crust.
Common "mafic elements" such as $\mathrm{Cr}, \mathrm{Ni}, \mathrm{Mg}$, Fe, and Ti are also depleted. These compositional characteristics would be expected if this magma was a partial melt of older crustal rocks and fractionated in a relatively oxidizing magma (see discussion of $\varepsilon_{\mathrm{Hf}}$ below).

\section{Geochronology}

We separated zircons from a sample of the coarsegrained rhyolite (DOM-1) by standard methods of crushing, grinding in a disk mill, heavy-liquid separation, and magnetic separation with a Franz Isodynamic Separator. These procedures yielded a large number of brownish-to-yellowish zircon grains, most of which exhibited prismatic forms. These were handpicked to obtain, as far as possible, grains with a minimum of inclusions and cracks, which were then mounted in epoxy for imaging and subsequent laser ablation-multicollector-ICPMS analysis.

Secondary electron, BSE, and cathodoluminescence (CL) images were obtained on a JEOL $8600 \mathrm{SEM} / \mathrm{mi}$ croprobe at Syracuse University. Representative CL images are presented in figure 7 . Note that the zircons have normal oscillatory zoning and do not display core-rim relations. Thus, we are confident that these zircons are of igneous origin and crystallized within the rhyolite magma. U-Pb analytical data for 52 grains were obtained with a Nu-Plasma MC-ICPMS attached to a New Wave 213-nm ultraviolet laser at the University of Florida. The zircon FC-1 was used as the analytical standard, for which we obtained ${ }^{206} \mathrm{~Pb} / 238 \mathrm{U}$ age of $1095 \pm 11 \mathrm{Ma}$ and ${ }^{207} \mathrm{~Pb} /{ }^{206} \mathrm{~Pb}$ age of $1098 \pm$

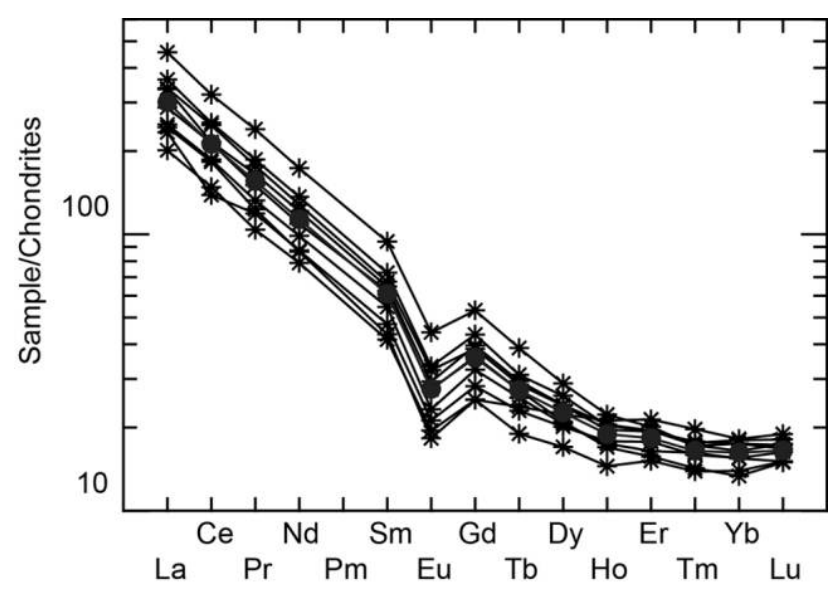

Figure 5. Chondrite-normalized rare earth element distribution of the nine samples (stars) and their average (filled circle) represent typical granitic distribution, with moderately negative Eu anomaly (0.57); after Sun and McDonough (1989). 


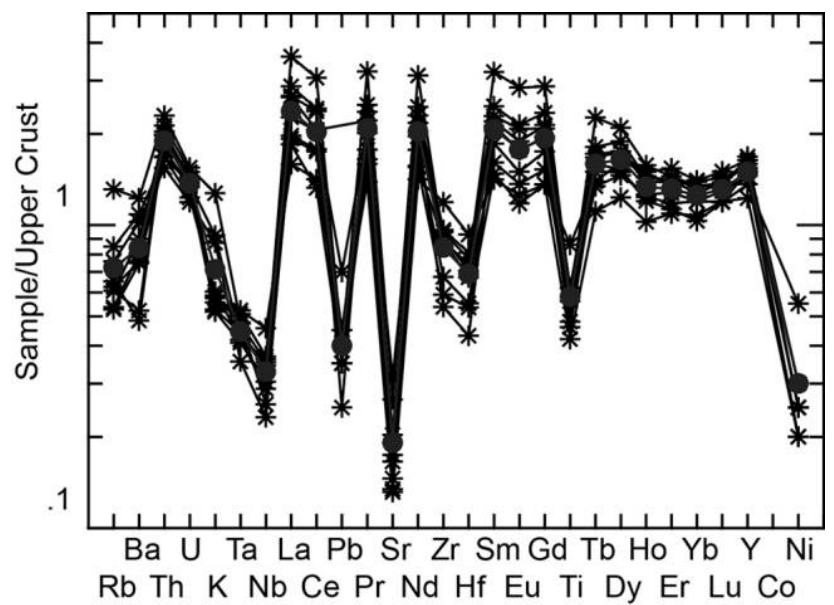

Figure 6. Upper continental crust-normalized plots of the samples (stars) and their average (filled circle), showing enrichments of felsic components and depletion of mafic components; after Rudnick and Fountain (1995) and Taylor and McLennan (1985).

$9 \mathrm{Ma}$, values that match the "true ages." Data were reduced with an in-house program, which included drift corrections. Results are given in table A2. When plotted on a standard concordia diagram, the data exhibited considerable scatter. We parsed the data by removing all analyses that were more than $10 \%$ discordant and analyses that plotted to the right of the concordant data, indicating presence of an inherited component. Interestingly, we observed an obvious inherited core in only one grain (DOM 61; table A2). In this zircon grain, the core yielded grossly discordant data, indicating an age only about $2 \%$ greater than that of the rim. After removing 23 analyses, we obtained the 29 data points plotted in figure 8 , top. These data are all essentially concor- dant and yield a regressed upper intercept age of $1640 \pm$ $4 \mathrm{Ma}$. Because the data are concordant, we also plotted the probability distribution (fig. 8, bottom left) and calculated the weighted-mean average of the ${ }^{207} \mathrm{~Pb} /{ }^{206} \mathrm{~Pb}$ ages (fig. 8, bottom right) from a data set of 46 analyses screened only at less than $10 \%$ discordant. This calculation yielded an age of $1642 \pm$ $7 \mathrm{Ma}$, at $95 \%$ confidence and MSWD $=7.4$, which we take to be the crystallization age of the rhyolite.

\section{Relation to Previously Determined Ages}

Porcellanite rocks in the Semri Group have been previously dated by Rasmussen et al. (2002) and Ray et al. (2002). In both studies zircons were separated from porcellanitic rocks, that is, fine-grained silicified ash beds. Ray et al. (2002) analyzed zircons from two samples for U-Pb by TIMS methods, obtaining essentially identical ages of $1631.2 \pm 5.4$ and $1630.7 \pm 0.8 \mathrm{Ma}$. Rasmussen et al. (2002) analyzed zircons from a porcellanite bed by SHRIMP methods, obtaining a "pooled" ${ }^{207} \mathrm{~Pb} /{ }^{206} \mathrm{~Pb}$ age of $1628 \pm 8 \mathrm{Ma}$. They also analyzed zircons from a porcellanite in the Rampur Shale, somewhat higher in the section, by SHRIMP, obtaining an age of $1599 \pm 8 \mathrm{Ma}$. It is interesting to compare these ages with the age of zircons (1642 $\pm 7 \mathrm{Ma})$ separated from coarse rhyolite (this study). Within $2 \sigma$ errors, the ages determined by Ray et al. and Rasmussen et al. are not analytically different, since each can be as great as $1636 \mathrm{Ma}$. Our newly determined age is analytically distinct, but only slightly so, for it can also be as young as $1635 \mathrm{Ma}$. Given the overall uncertainties of sampling and analytical errors, we consider all reported ages from the Porcellanite Formation to be identical. The age reported by Rasmussen et al. (2002) for the Rampur Shale porcellanite is,
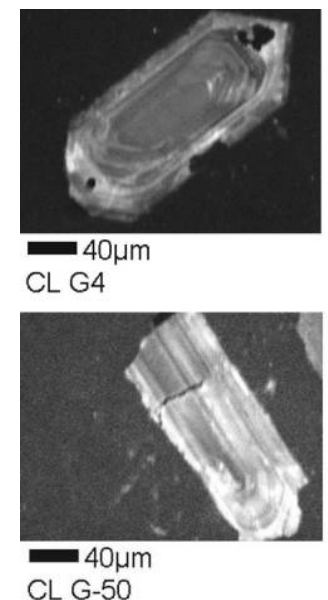

CL G-50

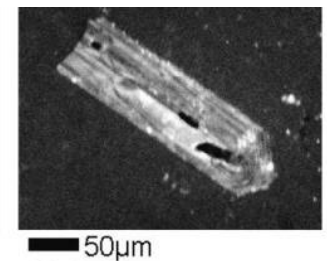

CL G-14

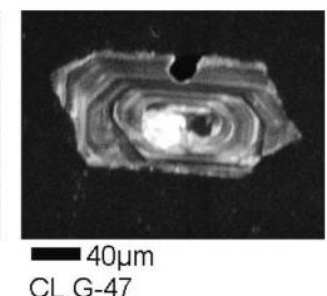

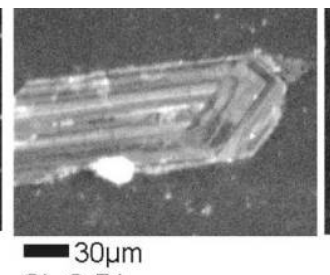
CL G-71

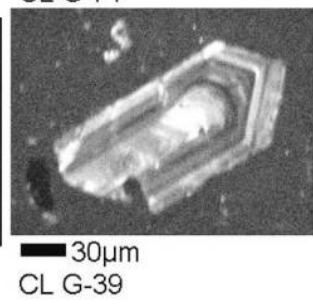

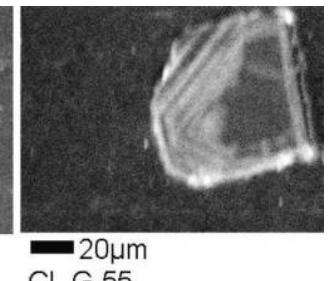

CL G-55

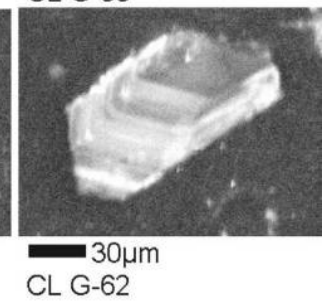

Figure 7. Representative cathodoluminescence (CL) images of zircons. 

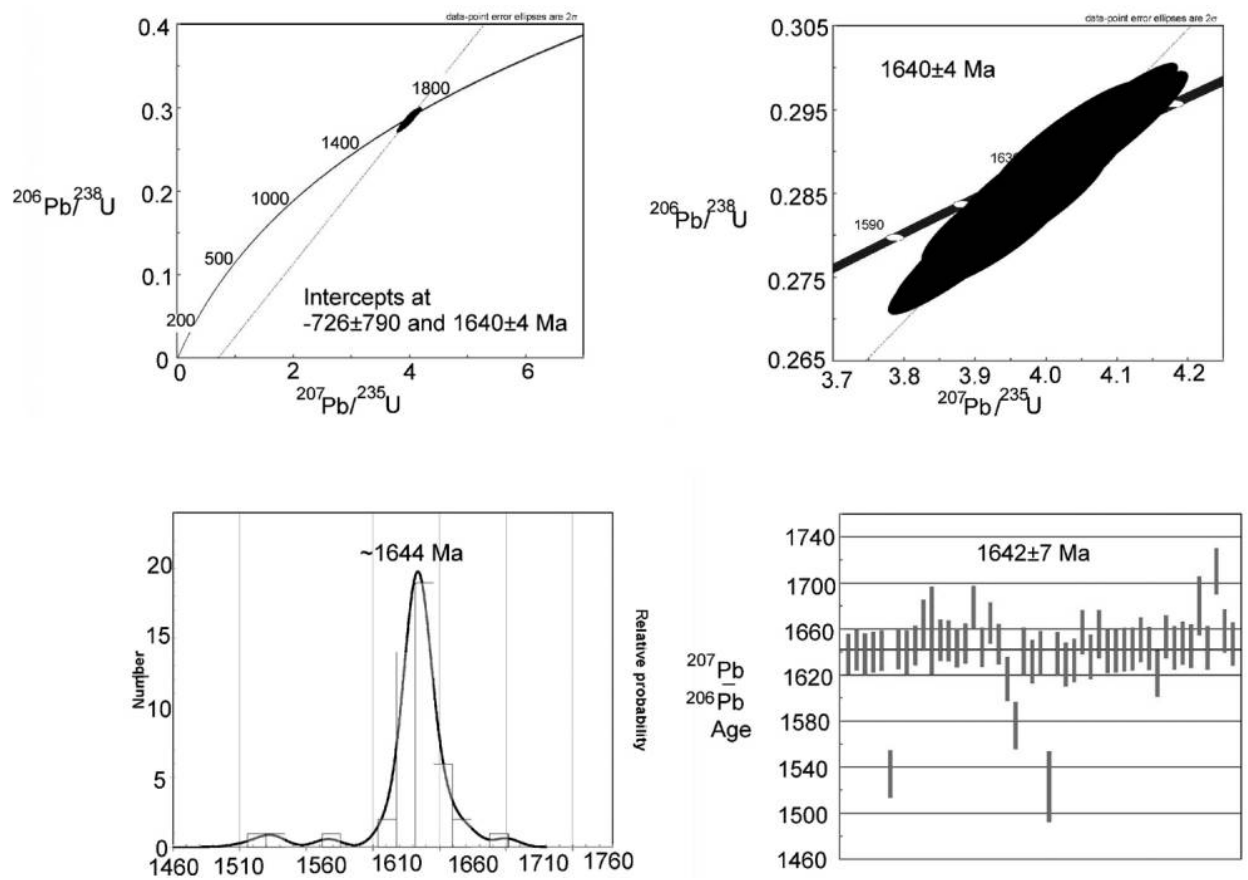

Figure 8. Top left, concordia plot; top right, detail of concordia plot. Bottom left, probability density plot of ${ }^{207} \mathrm{~Pb} /$ ${ }^{206} \mathrm{~Pb}$ ages. Bottom right, weighted average of ${ }^{207} \mathrm{~Pb} /{ }^{206} \mathrm{~Pb}$ ages. A color version of this figure is available online.

however, distinctly younger, consistent with its stratigraphic position higher in the section.

\section{Lu-Hf Isotope Geochemistry}

We obtained Lu-Hf isotopic compositions, also at the University of Florida, from the same zircons used for U-Pb measurements in order to investigate the sources of the rhyolitic magma. Zircon FC-1 was used as the standard for Lu-Hf analyses. FC-1 analyses, conducted together with analyses of DOM zircons $(n=6)$, yielded ${ }^{176} \mathrm{Hf} /{ }^{177} \mathrm{Hf}=$
$0.28216( \pm 0.00004,2 \mathrm{SE})$ or $\varepsilon_{\mathrm{Hf}}=-24.1( \pm 1.4,2 \mathrm{SE})$. The data (table A3) are presented as $\varepsilon_{\mathrm{Hf}}(1640 \mathrm{Ma})$ with errors; we have tabulated data only for those zircons that are less than $10 \%$ discordant, that is, the "screened" zircon grains. These data are plotted, at $1640 \mathrm{Ma}$, as $\varepsilon_{\mathrm{Hf}}$ versus age, with both chondrite uniform reservoir (CHUR) and depleted-mantle (DM) curves, in figure $9 A$ and as a probability density plot in figure $9 B$. It will be seen that $\varepsilon_{\mathrm{Hf}}$ values are uniformly low, with only one of 24 values greater than 0 (CHUR). These data indicate that the zircons, and thus the magma from which they crystallized, have
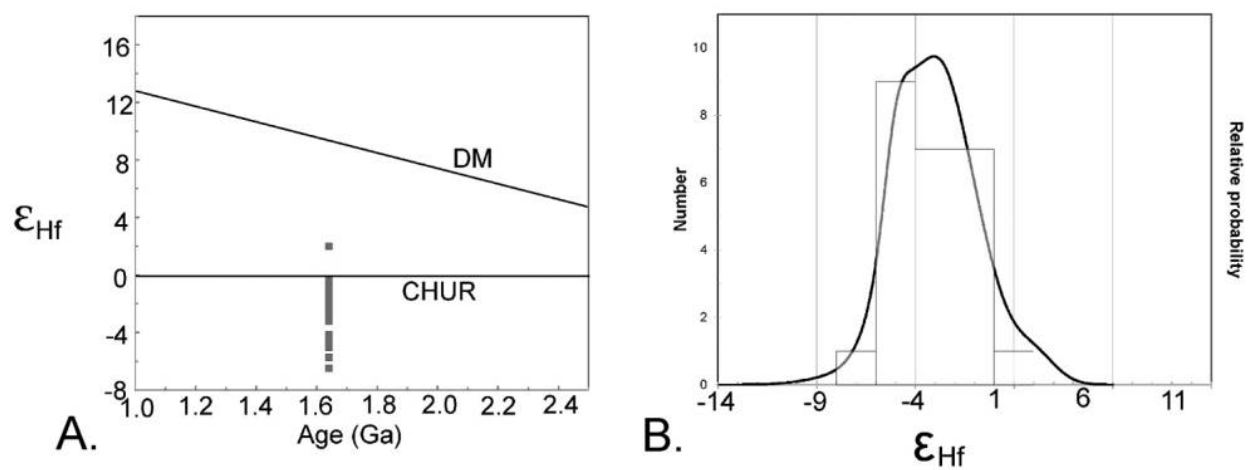

Figure 9. $A, \varepsilon_{\mathrm{Hf}}$ versus ${ }^{207} \mathrm{~Pb} /{ }^{206} \mathrm{~Pb}$ age, with chondrite uniform reservoir (CHUR) and depleted-mantle (DM) curves. $B$, Probability-density plot of $\varepsilon_{\mathrm{Hf}}$ values. A color version of this figure is available online. 


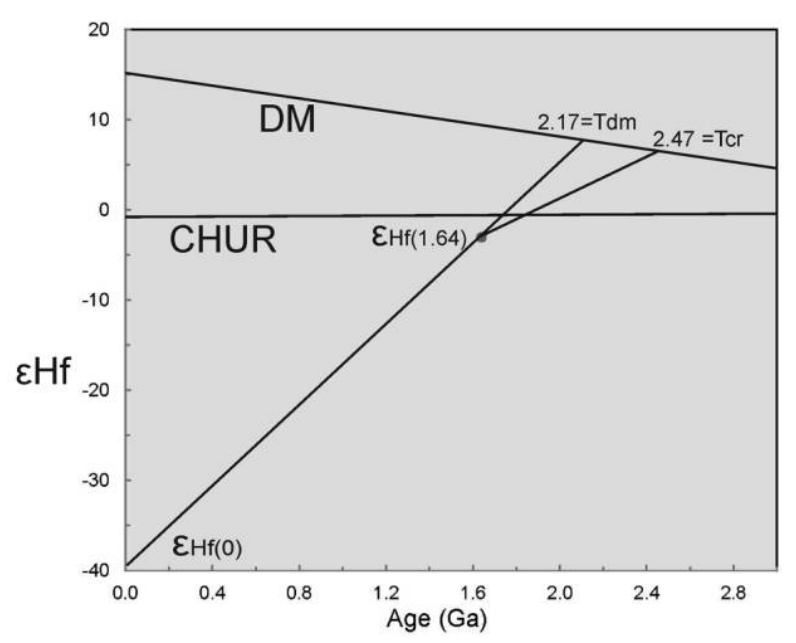

Figure 10. $\varepsilon_{\mathrm{Hf}}$ versus ${ }^{207} \mathrm{~Pb} /{ }^{206} \mathrm{~Pb}$ age, illustrating how $T_{\mathrm{DM}}$ and $T_{\mathrm{cr}}$ (depleted-mantle and crustal ages, respectively) are calculated. The point labeled $\varepsilon_{\mathrm{Hf}}(1.64)$ is the average $\varepsilon_{\mathrm{Hf}}$ at that time. The line from $\varepsilon_{\mathrm{Hf}(0)}$ projected to intersection with the DM curve on the basis of the ${ }^{176} \mathrm{Lu} /$ ${ }^{177} \mathrm{Hf}$ of the zircons determines the calculated $T_{\mathrm{DM}}$. The line from $\varepsilon_{\mathrm{Hf}}(1.64)$ back to the DM curve is projected on the basis of an assumed crustal ${ }^{176} \mathrm{Lu} /{ }^{177} \mathrm{Hf}$, in this case 0.0150 (Rudnick and Gao 2003). CHUR = chondrite uniform reservoir. A color version of this figure is available online.

incorporated relatively evolved $\mathrm{Hf}$ from the source of the magma. This suggests that the source was older crustal material. In addition, we have calculated (table A3) $T_{\mathrm{DM}}$ (DM model ages) that are based on the model of Nowell et al. (1998), as discussed by Mueller et al. (2008), and two-stage "crustal" model ages $\left(T_{\text {cri }}\right.$ e.g., Andersen et al. 2002) calculated on the basis of assumed crustal ${ }^{176} \mathrm{Lu} /{ }^{177} \mathrm{Hf}$ of $0.0083\left(T_{\mathrm{cr}}-1 ; \mathrm{UCC}\right.$; Rudnick and Gao 2003) or 0.0150 ( $T_{\mathrm{cr}}-2$; middle to lower crust). The relationships among $T_{\mathrm{DM}}$ model ages and $T_{\mathrm{cr}}$ model ages are illustrated in figure 10 . Average model ages are $T_{\mathrm{DM}}=2.16 \mathrm{Ga}, T_{\mathrm{cr}}-1=2.28 \mathrm{Ga}$, and $T_{\mathrm{cr}}-2=2.464 \mathrm{Ga}$. We emphasize that calculated model ages are only models, but the data clearly indicate that the DOM-1 rhyolite was derived - at least in large part-from partial melting of much older crustal rocks.

\section{Discussion}

The U-Pb age reported here for the true rhyolite flow in the Vindhyan basin records the oldest (1642 \pm $7 \mathrm{Ma}$ ) igneous activity after opening of the basin. The age complements, and is fully compatible with, other U-Pb zircon ages of the associated tuff beds. The new Lu-Hf isotopic data and our modeling of $\varepsilon_{\mathrm{Hf}}$ at $1640 \mathrm{Ma}$ indicate that this rhyolitic magma was derived, in large part, from melting of much older crustal rocks, perhaps as old as $2.5 \mathrm{Ga}$, consistent with age data for parts of the basement Bundelkhand Craton (e.g., Mondal et al. 2002; Kaur et al. 2014, 2016; Saha et al. 2016). Melting of such older crustal rocks would produce magma with the Hf isotopic composition of the melted rocks; assuming that melt temperatures exceeded zircon saturation temperatures, zircons crystallizing from such magma would inherit the Hf isotopic composition of the source rocks. On the assumption that crustal melting may have involved heat transfer from a mantle source, there could also have been a component of mantle material in the resulting magmas. However, the fairly substantial negative $\mathrm{Eu}$ anomaly (0.57), high $\mathrm{La} / \mathrm{Sc}$ and $\mathrm{Th} / \mathrm{Sc}$ ratios $(9.6$ and 2.8, respectively), and very low $\mathrm{Ni}$ and $\mathrm{Cr}$ contents of these rocks suggest that mafic-ultramafic components were minor contributors. Below we offer alternate tectonic scenarios that may have triggered crustal melting beneath the basin at this time.

First, Chakrabarti et al. (2007) have argued, on the basis of the $\varepsilon_{\mathrm{Nd}}$ of the porcellanites from near Chorhat at $1630 \mathrm{Ma}$ ("ranging from -5.7 to -0.9 ," p. 260), $\mathrm{Nb} / \mathrm{Ta}$-versus- $\mathrm{Zr} / \mathrm{Sm}$ plots, and $\mathrm{Ce} / \mathrm{Pb}$ versus-Ce plots, that the rhyolitic melt was derived from partial melting of mantle material, presumably in an Andean-type arc setting. Thus, in this scenario, the Vindhyan basin formed primarily on and at the edge of the Bundelkhand Craton as it was subducted southerly beneath a collisional arc forming in the south. If so, the rhyolitic melt and the ash of the Porcellanite Formation of the Semri Group erupted in an active margin. However, the Porcellanite Formation is sandwiched between the Kajrahat Limestone below and the shale-limestone units of the Koldaha Shale and Bargawan Limestone above (table 1). These limestones, which contain stromatolites (Kale and Phansalkar 1991; Bose et al. 2001; Misra and Kumar 2005; Banerjee et al. 2006; Srivastava and Tewari 2011) in association with felsic volcanic rocks, could hardly have accumulated at an active margin. Thus, we think it is unlikely that the rhyolitic volcanism was generated in an active-margin Andean-type arc setting. Also, the large area of flat-lying sediments seems contrary to an arc setting but is compatible with an extensional setting.

Second, Acharyya (2003) envisaged a foreland basin model for the Vindhyan Supergroup as the Bundelkhand Craton subducted in a southerly direction and the basin abutted against the uplifted (fold-thrust?) Mahakoshal Mobile Belt. In this scenario, the major source of sediments in the Semri Group would be not a magmatic arc but a recycled 
orogen, contradicting Chakrabarti et al. (2007). The new Hf isotopic data and the bulk geochemistry of the rhyolite do not contradict this model, although it is not clear how and why there would be crustal meting during Semri sedimentation. Note especially that foreland basins rarely have contemporaneous felsic volcanism. The scenarios of both Acharyya (2003) and Chakrabarti et al. (2007) call for a collision between the Bundelkhand and Bastar Cratons. On the basis of paleopole positions determined from nearly 50 mafic dikes in these two cratons, Radhakrishna et al. (2013) have ruled out any possibility of amalgamation of crustal blocks in this region in post-Archean time, especially at $\sim 1.8$ and $\sim 1.0 \mathrm{Ga}$, as had been noted in the literature. In addition, the above two conjectures do not consider that there are several other ash beds in the Vindhyan basin-specifically in the Kaimur and Rewa Groups-indicating "intrabasinal volcanism at multiple sites" (P. Chakraborty et al. 1996; Sen and Mishra 2014).

A third possibility is formation of the rhyolite in a (deep?) continental rift. Indeed, Bose et al. (2001) and Mishra (2015) have suggested so for the opening of the Semri basin. To be fair, they do not specifically address the origin of the multiple felsic volcanisms. However, this setting commonly leads to bimodal volcanism, as in the Proterozoic MidContinent Rift (North America) or in the Cenozoic East African Rift (Green and Fitz 1993; Corti 2009). Although the Porcellanite Formation and other ash beds extend for a long distance (over $300 \mathrm{~km}$ ), the volume of the volcanic material is small, and there are no published reports of coeval basaltic rocks. Further, there is no independent evidence for plate divergence below the Vindhyan basin at about $1640 \mathrm{Ma}$. We are unable to visualize (1) an active arc basin with extensive shallow-water stromatolite growth, (2) a foreland basin with repeated felsic volcanism, or (3) a (deep) continental rift caused by plate divergence without bimodal volcanism or without geophysical signals. Thus, one has to search for a different tectonic reason for the opening of the Semri basin and subsequent volcanism in the Vindhyan basin as a whole.

In our opinion, the most likely scenario is that farfield extension, related to collisions of continental blocks during supercontinent assembly, triggered melting at the base of the ca. $2.5 \mathrm{Ga}$ continental crust at about $1650 \mathrm{Ma}$, which needed some extension to enable the magmas to get to the surface. Several continental landmasses ( blocks) were assembled, and presumably attained their maximum packing, in the assembly of the Columbia Supercontinent (Rogers and Santosh 2004), by about $1600 \mathrm{Ma}$. The collisional boundaries of these blocks are com- monly marked by deformational evidence of orogeny and high- $P-T$ (pressure-temperature) granulites. For example, a granulite in the Central Indian Tectonic Zone is reported to have experienced its peak $P$ - $T$ at ca. $1658 \pm 12 \mathrm{Ma}$, and the associated heating events lasted for about $50 \mathrm{My}$ (U-Pb zircon; Bhowmik et al. 2014); the Krishna orogeny in southern India lasted from about 1.67 to about $1.55 \mathrm{Ga}$ (monazite; CHIME [chemical Th-U-total $\mathrm{Pb}$ isochron method]; Dobmeier and Raith 2003); a similar history is recorded in the adjacent Ongole Domain in the Eastern Ghats (Henderson et al. 2014); the Bhopalpatnam Granulite Belt (1.59 $\pm 0.03 \mathrm{Ga}$; monazite CHIME; Santosh et al. 2004) marks an amalgamation of the Bastar and Dharwar Cratons in south-central India; the Keshkal Granite (1639 \pm 40 Ma; Rb-Sr; Sarkar et al. 1990) putatively marks the end of a collisional event in the Bastar Craton; and the then-nearby Mangaroon orogeny in Australia (1680-1620 Ma with a peak at 1650 Ma; U-Pb SHRIMP: Sheppard et al. 2005; U-Pb monazite: Rasmussen et al. 2007) records a similar tectonic history. Any of these events, singly or in combination, may have triggered far-field fracturing and decompression melting that produced the rhyolitic volcanism in the Semri basin.

Although one or more of these events may have triggered crustal melting in the basement of the Lower Vindhyan Semri Group at ca. $1640 \mathrm{Ma}$, they were clearly subsequent to the initiation of Vindhyan sedimentation. The basal Lower Vindhyan sediments in the eastern Son valley were deposited nonconformably on the Paleoproterozoic Mahakoshal Group, within which the Jhirgadandi Granite has been dated at $1753 \pm 9 \mathrm{Ma}$ (Bora et al. 2013). Thus, the opening of the Vindhyan basin is constrained to later than ca. $1750 \mathrm{Ma}$ and earlier than $1642 \mathrm{Ma}$. Further, the Porcellanite Formation occurs about $150 \mathrm{~m}$-and perhaps $500 \mathrm{~m}$, by some accounts-above the Mahakoshal-Vindhyan unconformity (fig. 1). The Kairahat Limestone, which occurs below the Porcellanite Formation, has been dated at $1729 \pm 110 \mathrm{Ma}$ by $\mathrm{Pb}-\mathrm{Pb}$ methods (Sarangi et al. 2004). Taken together, these results suggest that the Vindhyan basin opened ca. $1740 \mathrm{Ma}$ and that sedimentation continued for about $100 \mathrm{My}$, until new volcanism occurred ca. $1640 \mathrm{Ma}$ in response to later tectonic events.

\section{A C K N O W LED GMENTS}

This research was supported by a grant (24/0310/ 10/EMR-II) provided by the Council of Scientific and Industrial Research, New Delhi, to M. Mishra and funding from Syracuse and Indiana Universi- 
ties. A National Science Foundation equipment grant to J. Schieber (EAR-0318769) provided funds for the purchase of the analytical scanning electron microscope that was used to acquire some of the data and images for this article. R. Droppo assisted in putting the illustrations together. N. Absar and an anonymous reviewer provided meticulous feedback that corrected and improved an earlier version of the article. S. Sarkar and S. Banerjee advised us on multiple felsic volcanisms in the Vindhyan basin. We thank all, and especially D. Rowley for expert editorial handling.

\section{REFERENCES CITED}

Acharyya, S. K. 2003. The nature of Mesoproterozoic Central Indian Tectonic Zone with exhumed and reworked older granulites. Gondwana Res. 6:197-214.

Andersen, T.; Griffin, W. L.; and Pearson, N. J. 2002. Crustal evolution in the SW part of the Baltic Shield: the Hf isotope evidence. I. Petrol. 43:1725-1747.

Auden, J. B. 1933. Vindhyan sedimentation in the Son Valley, Mirzapur District. Mem. Geol. Surv. India 62: 141-250.

Banerjee, S.; Bhattacharya, S. K.; and Sarkar, S. 2006. Carbon and oxygen compositions of the carbonate facies in the Vindhyan Supergroup, central India. I. Earth Syst. Sci. 115:113-134.

Bansal, A. R., and Dimri, V. P. 2001. Depth estimation from the scaling power spectral density of nonstationary gravity profile. Pure Appl. Geophys. 158:799812.

Bengston, S.; Belivanova, V.; Rasmussen, B.; and Whitehouse, M. 2009. The controversial "Cambrian" fossils of the Vindhyan are real but more than a billion years older. Proc. Natl. Acad. Sci. USA 106:7729-7734.

Bhattacharjee, S.; Mukherjee, A.; and Banerjee, I. 1964. On certain features of basement topography in the Vindhyan basin. Q. J. Geol. Mining Metall. Soc. India 36:119-125.

Bhattacharyya, A., ed. 1996. Recent advances in Vindhyan geology. Geol. Soc. India Mem. 36, 331 p.

Bhowmik, S. K.; Wilde, S. A.; Bhandari, A.; and Basu Sarbadhikari, A. 2014. Zoned monazite and zircon as monitors for the thermal history of granulite terranes: an example from the Central Indian Tectonic Zone. I. Petrol. 55:585-621.

Bora, S.; Kumar, S.; Yi, K.; Kim, N.; and Lee, T. H. 2013. Geochemistry and U-Pb SHRIMP zircon chronology of granitoids and microgranular enclaves from Jhirgadandi Pluton of Mahakoshal Belt, Central India Tectonic Zone, India. I. Asian Earth Sci. 70-71:99-114.

Bose, P. K.; Sarkar, S.; Chakrabarty, S.; and Banerjee, S. 2001. Overview of the Meso- to Neoproterozoic evolution of the Vindhyan basin, central India. Sediment. Geol. 141-142:395-419.

Bose, P. K.; Sarkar, S.; Das, N. G.; Banerjee, S.; Mandal, A.; and Chakraborty, N. 2015. Proterozoic Vindhyan basin: configuration and evolution. In Mazumder, R., and Eriksson, P. G., eds. Precambrian basins of India: stratigraphic and tectonic context. Geol. Soc. Lond. Mem. 43:85-102.

Bull, K. F., and McPhie, J. 2007. Fiamme textures in volcanic successions: flaming issues of definition and interpretation. J. Volcanol. Geotherm. Res. 164:205216.

Chakrabarti, R.; Basu, A. R.; and Chakrabarti, A. 2007. Trace element and Nd-isotopic evidence for sediment sources in the mid-Proterozoic Vindhyan basin, central India. Precambrian Res. 159:260-274.

Chakraborty, C. 2006. Proterozoic intracontinental basin: the Vindhyan example. I. Earth Syst. Sci. 115:3-22.

Chakraborty, P. P.; Banerjee, S.; Das, N. G.; Sarkar, S.; and Bose, P. K. 1996. Volcaniclastics and their sedimentological bearing in Proterozoic Kaimur and Rewa groups in central India. In Bhattacharyya, A., ed. Recent advances in Vindhyan geology. Geol. Soc. India Mem. 36:59-75.

Chakraborty, T.; Sarkar, S.; Chaudhuri, A. K.; and Dasgupta, S. 1996. Depositional environment of Vindhyan and other Purana basins: a reappraisal in the light of recent findings. In Bhattacharyya, A., ed. Recent advances in Vindhyan geology. Geol. Soc. India Mem. 36:101-126.

Corti, G. 2009. Continental rift evolution: from rift initiation to incipient break-up in the Main Ethiopian Rift, East Africa. Earth-Sci. Rev. 96:1-53.

Dobmeier, C. J., and Raith, M. M. 2003. Crustal architecture and evolution of the Eastern Ghats Belt and adjacent regions of India. In Yoshida, M.; Windley, B. F.; and Dasgupta, S., eds. Proterozoic East Gondwana: supercontinent assembly and breakup. Geol. Soc. Lond. Spec. Publ. 206:145-168.

Ghosh, S. K. 1971. Petrology of the porcellanite rocks of Samaria area, Sidhi District, Madhya Pradesh. Q. J. Geol. Mining Metall. Soc. India 43:153-164.

Green, J., and Fitz, T. 1993. Extensive felsic lavas and rheoignimbrites in the Keweenawan Midcontinent Rift plateau volcanics, Minnesota: petrographic and field recognition. J. Volcanol. Geotherm. Res. 54:177196.

Henderson, B.; Collins, A. S.; Payne, J. L.; Forbes, C. J.; and Saha, D. 2014. Geologically constraining India in Columbia: the age, isotopic provenance and geochemistry of the protoliths of the Ongole Domain, southern Eastern Ghats, India. Gondwana Res. 26:888-906.

Kale, V. S., and Phansalkar, V. G. 1991. Purana basins of peninsular India: a review. Basin Res. 3:1-36.

Kaur, P.; Zeh, A.; and Chaudhri, N. 2014. Characterisation and $\mathrm{U}-\mathrm{Pb}-\mathrm{Hf}$ isotope record of the $3.55 \mathrm{Ga}$ felsic crust from the Bundelkhand Craton, northern India. Precambrian Res. 255:236-244.

Kaur, P.; Zeh, A.; Chaudhri, N.; and Eliyas, N. 2016. Unravelling the record of Archaean crustal evolution 
of the Bundelkhand Craton, northern India using $\mathrm{U}-\mathrm{Pb}$ zircon-monazite ages, Lu-Hf isotope systematics, and whole-rock geochemistry of granitoids. Precambrian Res. 281:384-413.

Kumar, S., and Sharma, M. 2010. Vindhyan basin, Son Valley Area, Central India: field guide. Lucknow, Paleontological Society of India, $121 \mathrm{p}$.

Mallet, F. R. 1869. On the Vindhyan Series, as exhibited in the north-western and central provinces of India. Mem. Geol. Surv. India 7:1-129.

Mathur, S. M. 1982. Precambrian sedimentary sequences of India: their geochronology and correlation. Precambrian Res. 18:139-144.

Mehrotra, M. N.; Banerjee, R.; Dalela, R. K.; and Lal, P. 1985. The Son Porcellanite Formation: an example of volcaniclastic sedimentation in India. Indian J. Earth Sci. 12:21-33.

Mishra, D. C. 2015. Plume and plate tectonics model for formation of some Proterozoic basins of India along contemporary mobile belts: Mahakoshal-Bijawar, Vindhyan and Cuddapah basins. I. Geol. Soc. India 85:525536.

Mishra, M., and Sen, S. 2010. Geochemistry and origin of Proterozoic porcellanitic shales from Chopan, Vindhyan basin, India. Indian J. Geol. 80:157-171.

Misra, Y., and Kumar, S. 2005. Coniform stromatolites and the Vindhyan Supergroup, central India: implications for basinal correlation and age. J. Paleontol. Soc. India 50:153-167.

Mondal, M. E. A.; Goswami, J. N.; Deomurari, M. P.; and Sharma, K. K. 2002. Ion microprobe ${ }^{207} \mathrm{~Pb} /{ }^{206} \mathrm{~Pb}$ ages of zircons from the Bundelkhand massif, northern India: implications for crustal evolution of the BundelkhandAravalli protocontinent. Precambrian Res. 117:85-100.

Mueller, P. A.; Kamenov, G. D.; Heatherington, A. L.; and Richards, J. 2008. Crustal evolution in the southern Appalachian orogen: evidence from $\mathrm{Hf}$ isotopes in detrital zircons. I. Geol. 116:414-422.

Nowell, G. M.; Kempton, P. D.; Noble, S. R.; Fitton, J. G.; Saunders, A. D.; Mahoney, J. J.; and Taylor, R. N. 1998. High precision $\mathrm{Hf}$ isotope measurements of MORB and OIB by thermal ionisation mass spectrometry: insights into the depleted mantle. Chem. Geol. 149:211233.

Pearce, J. A. 1996. A user's guide to basalt discrimination diagrams. In Wyman, D. A., ed. Trace element geochemistry of volcanic rocks: applications for massive sulphide exploration. Geol. Assoc. Can. Short Course Notes, no. 12. p. 79-113.

Prasad, B., and Asher, R. 2016. Record of Ediacaran complex acanthomorphic acritarchs from the Lower Vindhyan succession of the Chambal valley (east Rajasthan), India and their biostratigraphic significance. J. Paleontol. Soc. India 61:29-62.

Radhakrishna, T.; Chandra, R.; Srivastava, A. K.; and Balasubramonian, G. 2013. Central/eastern Indian Bundelkhand and Bastar Cratons in the Palaeoproterozoic supercontinental reconstructions: a palaeomagnetic perspective. Precambrian Res. 226:91-104.
Ramakrishnan, M., and Vaidyanadhan, R. 2010. Geology of India. Vol. 1. Bangalore, Geological Society of India, $552 \mathrm{p}$.

Rasmussen, B.; Bose, P. K.; Sarkar, S.; Banerjee, S.; Fletcher, I. R.; and McNaughton, N. J. 2002. 1.6 Ga U-Pb zircon age for the Chorhat Sandstone, Lower Vindhyan, India: possible implications for early evolution of animals. Geology 30:103-106.

Rasmussen, B.; Fletcher, I. R.; Muhling, J. R.; Thorne, W. S.; and Broadbent, G. C. 2007. Prolonged history of episodic fluid flow in giant hematite ore bodies: evidence from in situ U-Pb geochronology of hydrothermal xenotime. Earth Planet. Sci. Lett. 258:249-259.

Ray, J. S.; Martin, M. W.; Veizer, J.; and Bowring, S. A. 2002. $\mathrm{U}-\mathrm{Pb}$ zircon dating and $\mathrm{Sr}$ isotope systematics of the Vindhyan Supergroup, India. Geology 30:131-134.

Ray, J. S.; Veizer, J.; and Davis, W. J. 2003. C, O, Sr and $\mathrm{Pb}$ isotope systematics of carbonate sequences of the Vindhyan Supergroup, India: diagenesis, correlations and implications for global events. Precambrian Res. 121: 103-140.

Rogers, J. J. W., and Santosh, M. 2004. Continents and supercontinents. Oxford, Oxford University Press, 289 p.

Rudnick, R. L., and Fountain, D. L. 1995. Nature and composition of the continental crust: a lower crustal perspective. Rev. Geophys. 33:267-309.

Rudnick, R. L., and Gao, S. 2003. Composition of the continental crust. In Rudnick, R. L., ed. The crust. Vol. 3 of Holland, H. H., and Turekian, K. K., eds. Treatise on geochemistry. Oxford, Elsevier-Pergamon, p. 1-64.

Saha, L.; Frei, D.; Gerdes, A.; Pati, J. K.; Sarkar, S.; Patole, V.; Bhandari, A.; and Nasipuri, P. 2016. Crustal geodynamics from the Archaean Bundelkhand Craton, India: constraints from zircon U-Pb-Hf isotope studies. Geol. Mag. 153:179-192.

Santosh, M.; Yokoyama, K.; and Acharyya, S. K. 2004. Geochronology and tectonic evolution of Karimnagar and Bhopalpatnam granulite belts, central India. Gondwana Res. 7:501-518.

Sarangi, S.; Gopalan, K.; and Kumar, S. 2004. Pb-Pb age of earliest megascopic, eukaryotic alga bearing Rohtas Formation, Vindhyan Supergroup, India: implications for Precambrian atmospheric oxygen evolution. Precambrian Res. 132:107-121.

Sarkar, G.; Paul, D. K.; de Laeter, J. R.; McNaughton, N. J.; and Misra, V. P. 1990. A geochemical and Pb, $\mathrm{Sr}$ isotopic study of the evolution of granite-gneisses from the Bastar Craton, central India. J. Geol. Soc. India 35:481-496.

Sen, S., and Mishra, M. 2014. Tuffaceous beds from Bijaigarh Shale, Vindhyan Supergroup, central India: an evidence of volcanism [abs.]: International Seminar on Magmatism, Tectonism and Mineralization (MTM2014), Kumaun University, Nainital. Int. Assoc. Gondwana Res. Conf. Ser. 18:55-56.

Sheppard, S.; Occhipinti, S.; and Nelson, D. 2005. Intracontinental reworking in the Capricorn orogen, Western Australia: the $1680 \mathrm{Ma}$ Mangaroon orogeny. Aust. I. Earth Sci. 52:443-460. 
Singh, K. N., and Srivastava, R. N. 1982. On the occurrence of ash-tuff cone structures from the Porcellanite Formation, Chopan area, Mirzapur District, Uttar Pradesh. Indian J. Earth Sci. 10:107-109.

Srivastava, P., and Tewari, V. C. 2011. Morphological changes in microscopic-megascopic life and stromatolites recorded during Late Palaeoproterozoic-Neoproterozoic transition: the Vindhyan Supergroup, India. In Tewari, V. C., and Seckbach, J., eds. Stromatolites: interaction of microbes with sediments. Dordrecht, Springer, p. 87114.

Srivastava, R. N.; Srivastava, A. K.; Singh, K. N.; and Redcliffe, R. P. 2001. Precambrian acidic volcanism in the lower Vindhyan basin of the Sonbhadra District and adjoining areas of Uttar Pradesh: a review. Spec. Publ. Ser. Geol. Surv. India 55:205-218.
2003. Sedimentation and depositional environment of the Chopan Porcellanite Formation, Semri Group, Vindhyan Supergroup in parts of Sonbhadra District, Uttar Pradesh. J. Paleontol. Soc. India 48:167-179.

Sun, S. S., and McDonough, W. F. 1989. Chemical and isotopic systematics of oceanic basalts: implications for mantle composition and processes. In Saunders, A. D., and Norry, M. J., eds. Magmatism and ocean basins. Geol. Soc. Lond. Spec. Publ. 42:313-345.

Taylor, S. R., and McLennan, S. M. 1985. The continental crust: its composition and evolution. Oxford, Blackwell, $312 \mathrm{p}$.

Winchester, J. A., and Floyd, P. A. 1977. Geochemical discrimination of different magma series and their differentiation products using immobile elements. Chem. Geol. 20:325-343. 